\title{
A comparison of dual-functional whey hydrolysates by the use of commercial proteases
}

\author{
Luísa Ozorio Lopes da ROSA ${ }^{1}$, Marcelo Cerutti SANTANA ${ }^{2}$, Tatiana Lima AVEZEDO ${ }^{3}$, \\ Ana Iraidy Santa BRÍGIDA³ ${ }^{3}$, Ronoel GODOY ${ }^{3}$, Sidney PACHECO ${ }^{3}$, Caroline MELLINGER-SILVA ${ }^{3 *}$, \\ Lourdes Maria Correa CABRAL ${ }^{3}$
}

\begin{abstract}
Whey is well-known for the functional and bioactive properties of its proteins and peptides, which are of great interest to food and nutraceutical industries. The aim of this study was to investigate the effect of four different commercial proteases (Novo ProD ${ }^{\circledR}$ (NPD), Alcalase ${ }^{\circledR}$ (ALC), Pancreas Trypsin ${ }^{\circledR}$ (TRY), and Flavourzyme ${ }^{\circledR}$ (FLA)) in the generation of hydrolysates with emulsifying and antioxidant activities. Hydrolysis processes were carried out for $5 \mathrm{~h}$, reaching maximum degrees of 18.5, 15.5, 9.2, and 8.7\% for NPD, ALC, TRY, and FLA, respectively. All tested enzymes generated very diverse, but conservative peptide profiles when comparing the treatments along the time, with the main enzymatic actions up to 120 min-reaction. An increase in the in vitro antioxidant activity was found for all treatments, achieving $46 \%, 40 \%, 40 \%$ and $22 \%$ for ALC, TRY, NDP and FLA, respectively. TRY hydrolysate maintained or slightly increased its emulsifying capacity along the time, however, a decrease in emulsifying capacity was found for ALC and NPD hydrolysates when compared to the non-hydrolyzed whey protein concentrate (WPC). All tested enzymes generated hydrolysates with enhanced antioxidant and/or emulsifying activities, which may be used as food ingredients and the choice of the enzyme will depend on the need.
\end{abstract}

Keywords: whey protein; hydrolysis; functionality; emulsification; antioxidant activity.

Practical Application: Four proteases were evaluated for the generation of dual functional whey hydrolysates.

\section{Introduction}

Whey proteins are well known and widely consumed for being a high quality protein source especially incorporated into sports and nutrition products (West et al., 2017). Different commercial ingredients and products are available in the market, including whey powders (WP), whey protein concentrates (WPC) and whey protein isolates (WPI) which are classified according to the protein content, varying from less than 30\% for WP to 30-90\% for WPC and above 90\% for WPI (Whipple \& Eckhardt, 2016). In general, higher protein contents will result into better-valued products, mainly to attend nobler uses, as in the market of infant formulas and nutraceutical products.

Annual whey generation is estimated in 240 million metric tons (Mordor Intelligence, 2017). Besides its nutritional and technological properties, whey presents elevated organic matter content, generating high biological and chemical oxygen demands which cause environmental concerns (Sultana et al., 2016). In this sense, industrial interest in the use of whey has been growing, aiming to concentrate and dry whey proteins into different ingredients mainly to attend food industries.

Whey proteins are also known for the bioactivity of its peptides, which can be liberated through hydrolysis processes catalyzed by chemical or enzymatic agents. The use of enzymes has gained popularity since their specificity for some active-sites, results into ingredients and products with enhanced specialized properties, particularly in terms of biological functionalities (Le Maux et al., 2016; Ojha et al., 2016).

Among the main investigated biological properties from whey peptides, which comprise beneficial results for the cardiovascular, nervous, gastrointestinal, and immune systems, antioxidant activity is of relevance (Cánovas et al., 2017). The ability of peptides to interact with radical species or inhibit oxidative reactions is important for the body to prevent a number of age-specific diseases and neurodegenerative disorders caused by the oxidative stress. In food, oxidative reactions may shorten shelf life through deterioration of food quality worsening sensorial and nutritional aspects (Dryáková et al., 2010; Power et al., 2013). Thus, the possibility of using a natural antioxidant from a dietary source can be interesting and may even replace noxious, synthetic compounds.

In addition to the bio-functionalities, whey peptides may also enhance technological properties of food formulations, such as water binding, solubility, gelation, and emulsification (Madadlou \& Abbaspourrad, 2017), and the possibility of joining both bio and technological functionalities is also of interest for the food industry sector. In this way, the objective of this study was to compare WPC hydrolyses of four commercial proteases, considering both the antioxidant activity and emulsifying capacity of the hydrolysates. 


\section{Materials and methods}

\subsection{Materials}

A spray-dried whey protein concentrate (WPC 35) from bovine milk, of $34 \%$ (w/w) protein, was gently donated by Alibra Ingredientes Ltda (Paraná, Brazil), and was used as substrate. Enzymes were gently donated from Novozymes Latin America Ltda (Paraná, Brazil) and were used as recommended by the manufacturer in terms of enzyme concentration, optimal temperature, $\mathrm{pH}$ and the conditions for enzyme inactivation. Reagents were of high purity and purchased from Sigma-Aldrich (St. Louis, USA) or Merck (Darmstadt, Germany).

\section{Enzymatic hydrolysis}

WPC hydrolysates were prepared by suspending the powder in ultrapure water at a concentration of $24 \%(w / v)$, corresponding to $8.2 \mathrm{~g}$ of protein in $100 \mathrm{~mL}$ of suspended whey. The suspension was then continually stirred $(350 \mathrm{rpm})$ and the hydrolysis conditions were kept as indicated in Table 1. Prior the reaction, the systems were allowed to rehydrate and solubilize for $30 \mathrm{~min}$. The suspension was then adjusted to the adequate $\mathrm{pH}$ using aq. $\mathrm{NaOH}(1.0 \mathrm{M})$. At this point, an aliquot (control - C) was collected. The enzymes were then added to each system as recommended by the manufacturer. Values of $\mathrm{pH}$ and temperature were monitored along the reaction. Aliquots were collected after $1 \mathrm{~min}$ (T0), $60 \mathrm{~min}$ (T1), $120 \mathrm{~min}$ (T2), $180 \mathrm{~min}$ (T3), $240 \mathrm{~min}$ (T4), and $300 \mathrm{~min}$ (T5) of hydrolysis. All hydrolyzed samples were heated at $85^{\circ} \mathrm{C}$ for $15 \mathrm{~min}$ to inactivate the enzymes, and then cooled down under running tap water $\left(18^{\circ} \mathrm{C}\right)$. Samples were freeze-dried (Liotop, São Paulo, Brazil) then kept at $-20{ }^{\circ} \mathrm{C}$ for further analyses. Degree of hydrolysis (DH \%) was determined by the volume of base consumed, according to the pH-stat method (Adler-Nissen, 1986).

\section{Chromatographic analysis of peptides and proteins}

RP-HPLC was used to analyze the peptide profiles generated from the hydrolysis processes. An analytical HPLC unit (Waters - Alliance, separation module 2695, São Paulo, Brazil) with a C18 column, held at $30^{\circ} \mathrm{C}$, was used. Gradient elution was carried out by the use of two solvents. Solvent A: 0.1\% trifluroacetic acid (TFA) in ultrapure water (v/v), and Solvent B: $0.1 \%$ TFA in acetonitrile $(\mathrm{ACN})(\mathrm{v} / \mathrm{v})$. Hydrolysates were eluted as follows: 0 - 2 min, $95 \%$ A; 2 - 15 min, 95 - 80\% A; 15 - 20 min, 80 - 70\% A; 20 - 25 min, 70 - 60\% A; 25 - 28 min, 60 - 50\% A; 28 - 32 min,

Table 1. Hydrolysis conditions of WPC 35 by the use of different enzymes.

\begin{tabular}{ccccc}
\hline \multicolumn{5}{c}{ Hydrolysis Conditions $^{\mathbf{a}}$} \\
\hline Enzymes $^{\mathbf{b}}$ & {$[\mathbf{E} / \mathbf{S}]^{\mathbf{c}}$} & $\mathbf{p H}$ & $\mathbf{T}\left({ }^{\circ} \mathbf{C}\right)$ & EIC $^{\mathbf{d}}$ \\
\hline ALC & $2 \%(w / v)$ & 8.0 & 65.0 & $85^{\circ} \mathrm{C} / 15^{\prime}$ \\
NPD & $7 \%(w / v)$ & 9.0 & 50.0 & $80^{\circ} \mathrm{C} / 15^{\prime}$ \\
TRY & $1 \%(w / v)$ & 8.5 & 47.0 & $80^{\circ} \mathrm{C} / 15^{\prime}$ \\
FLA & $3 \%(w / v)$ & 7.0 & 50.0 & $80^{\circ} \mathrm{C} / 10^{\prime}$ \\
\hline
\end{tabular}

(a) hydrolysis conditions were set according to the manufacturer recommendation; (b) $\mathrm{ALC}=$ Alcalase $2.4 \mathrm{~L} \mathrm{FG}^{\circledR}$; NPD $=$ Novo-Pro ${ }^{\circledR}$; TRY = Pancreas Trypsin $6.0 \mathrm{~S}^{\circledR}$; FLA = Flavourzyme1.000L ${ }^{\circledR}$. (c) E/S = enzyme: substrate concentration; (d) EIC = Enzyme Inactivation Condition; $\mathrm{T}\left({ }^{\circ} \mathrm{C}\right)=$ temperature in Celsius degrees.
$50-40 \%$ A; 32 - $34 \min , 40-30 \%$ A; $34-36 \min , 30-20 \%$ A; 36 - $38 \mathrm{~min}, 20$ - 95\% A; 38 - $40 \mathrm{~min}, 95 \% \mathrm{~A}$. The flow rate was $1.0 \mathrm{~mL} \mathrm{min-1,} \mathrm{and} \mathrm{the} \mathrm{detection} \mathrm{was} \mathrm{at} 216 \mathrm{~nm}$ (Waters PDA Detector, 2996). Total running time was $40 \mathrm{~min}$. For the chromatographic analysis, freeze-dried samples were suspended into ultrapure water $\left(2 \mathrm{mg} \mathrm{mL}^{-1}\right)$ and $20 \mu \mathrm{L}$ was injected. Bovine $\alpha$-lactoalbumin ( $\alpha$-la) and $\beta$-lactoglobulin $(\beta-\lg )$ were used as standards, and the retention times were 28.20 and $31.85 \mathrm{~min}$, respectively.

\section{In vitro Antioxidant Activity}

The in vitro antioxidant activity of hydrolysates were measure by scavenging of the ABTS radical (ABTS $\bullet+)(2,2$ '-azinobis (3-ethylbenzothiazoline-6-solfonic acid)) using a decolorization assay (Re et al., 1999). 0.1M aq. phosphate-buffered saline (PBS) was used in $\mathrm{pH}$ 7.4. Spectrophotometric (Micronal, São Paulo, Brazil) reading was done 6 min after the addition of ABTS•+, in triplicate (Dryáková et al., 2010). The antioxidant activity was calculated as antioxidant activity \% (AA \%), following the equation 1:

$A A \%=[($ Abs blank - Abs sample $) /$ Abs blank $) * 100$

\section{Emulsifying Capacity (EC)}

Hydrolysates EC were evaluated by the emulsifying index of the sample in hexadecane according to Mellinger-Silva et al. (2015), right after hydrolyses processes, as soon as the hydrolysates cooled down from the enzyme inactivation. $1 \mathrm{~mL}$ of each hydrolysate was added of $1 \mathrm{~mL}$ of hexadecane in a tube test, and the tube was submitted to vigorous and non-interrupted stirring for $3 \mathrm{~min}$. Then, tubes reposed for $24 \mathrm{~h}$. The emulsifying capacity (EC\%) was calculated by using digital pachymetric measures (200 mm, IP67, PD202, Vonder, PR, Brazil) of the total solution height ( $\mathrm{Ht})$ and the emulsified phase height $(\mathrm{He})$, as shown by the equation 2 :

$E C(\%)=(H e / H t) * 100$

\section{Results and discussion}

\subsection{Hydrolysis of WPC and peptide profile of the hydrolysates}

The degree of hydrolysis (DH) of WPC differed significantly when comparing the results among the tested enzymes (Figure 1). NPD and ALC presented higher DH\%: 18.5 and 15.5, respectively. In both curves it was possible to observe a rapid and intense enzymatic activity until 90 min-reaction, heading to a plateau after 120 min reaction. NPD and ALC were both obtained from Bacillus licheniformis and present endopeptidase activity, with a broad possibility of cleavage. The peptide profiles of NPD and ALC (Figure 2) were similar, with intense signals from 4 to $22 \mathrm{~min}$ of the chromatograms. HPLC analyses corroborated with the data from $\mathrm{DH}$, showing that the main peaks were generated from 1 to $120 \mathrm{~min}$ and maintained up to $300 \mathrm{~min}$-reaction. Both enzymes rapidly degraded $\alpha$-la, while $\beta-\lg$ was just partially hydrolyzed along the reaction. $\beta$-lg is a globular protein which exists as a dimer at physiological $\mathrm{pH}$ and temperature, and two 


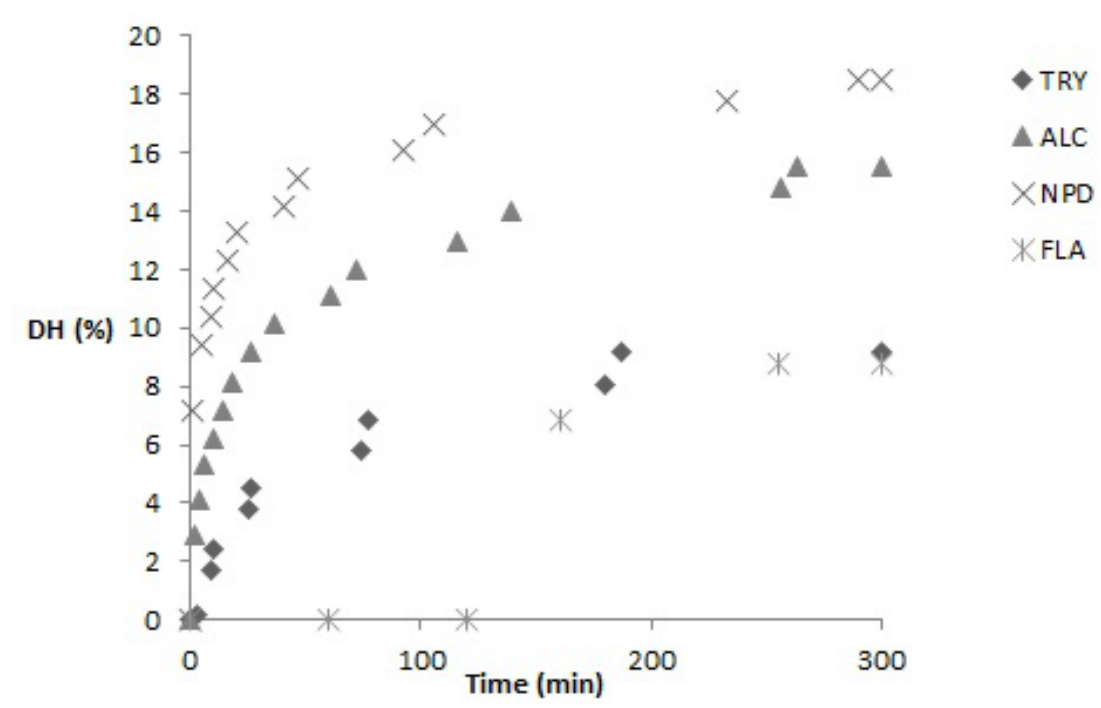

Figure 1. Degree of hydrolysis of whey protein concentrate (WPC) by the use of commercial proteases. DH\% was determined by the volume of base consumed, according to the $\mathrm{pH}$-stat method. (ALC) alcalase, (NPD) novo pro D, (TRY) pancreas trypsin, and (FLA) flavourzyme.

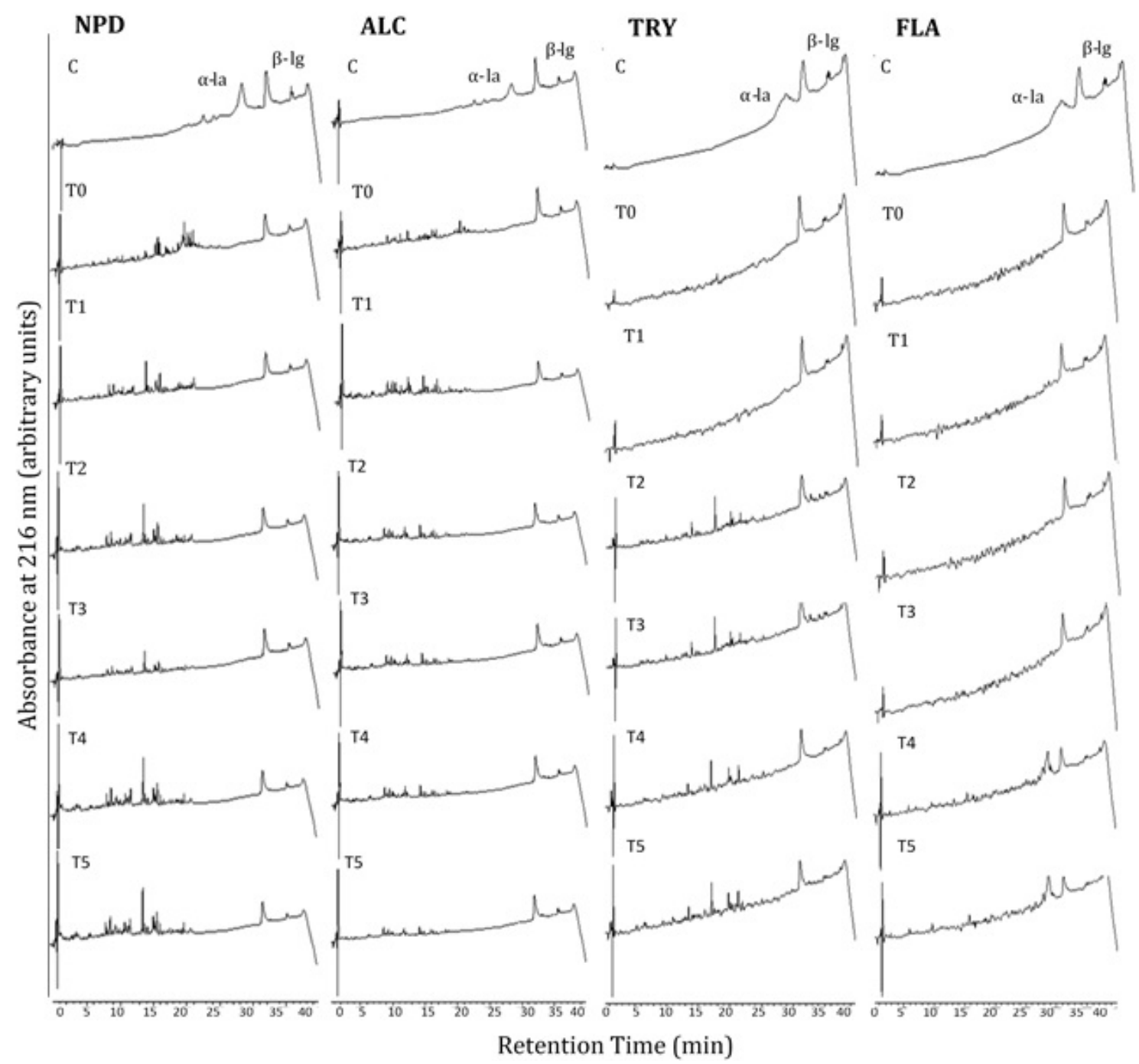

Figure 2. Chromatographic peptide profiles of whey protein concentrate (WPC) hydrolysates. (ALC) alcalase, (NPD) novo pro D, (TRY) pancreas trypsin, and (FLA) flavourzyme. (a) $\alpha$-lactoalbumin; (b) $\beta$-lactoglobulin, $\mathrm{C}=$ control sample; T0, T1, T2, T3, T4, T5 = aliquots collected in $1,60,120,180,240$ and 300 min-reaction. 
disulfide bonds are responsible for its globular stable structure. However, the exposure of $\beta$-lg to high temperatures or basic $\mathrm{pH}$ $(\mathrm{pH}>8)$ generate certain instability to protein's structure, causing dimer's dissociation, which is probably related to the greatest degrees found for the WPC hydrolyses with NPD (pH 9.0) and ALC (pH 8.0) (Cheison et al., 2010; Hernández-Ledesma et al., 2008).

TRY and FLA showed lower DH\% of 9.2 and $8.7 \%$, respectively. Hydrolytic curves (Figure 1) were similar among themselves, but different from the previous ones. Intense hydrolyses were observed up to $180 \mathrm{~min}$ reactions for the treatments with both enzymes. TRY is an endoprotease from animal origin that hydrolyses the carboxyl-side of lysine and arginine, and such amino acid specificity may explain a lower $\mathrm{DH}$. Complementing this result, the peptide profile of TRY (Figure 2) was not so varied, but showed an intense peak at $17.17 \mathrm{~min}$ that was maintained from the first hour of hydrolysis on.

On the other hand, FLA, a crude fungal enzyme formula from Aspergillus oryzae, declared by the manufacturer to present both endo- and exo-peptidase activities, showed the lowest $\mathrm{DH}$ and the poorest peptide profile, with only partial cleavage of $\alpha$-la and no action on the $\beta$-lg structure. The stability of the $\beta-\lg$ structure varies according the $\mathrm{pH}$, while in solutions with $\mathrm{pH}>8$ it shows certain instability, in $\mathrm{pH}<8$ it tends to form molecular aggregates, preventing enzyme's access to the amino acid residues that has affinity, which may explain the lowest degree of hydrolysis presented by FLA. (Cheison et al., 2010).

\subsection{In vitro antioxidant activity of whey hydrolysates}

All hydrolysates showed an increase in the in vitro antioxidant activity (AA) when measured by the ABTS assay, which is a colorimetric method widely used for food matrices and is applicable to water-soluble and lipid-soluble antioxidants, pure compounds, and food extracts. It is based on the reduction of the radical 2,2' -azinobis (3-etilbenzotiazolin-6-sulfonic acid - ABTS.+), which can be generated through chemical, electrochemical or enzymatic reaction. The quantity of radical consumed by the antioxidant substance is expressed as TEAC - trolox equivalent antioxidant capacity (Dryáková et al., 2010; Power et al., 2013; Zulueta et al., 2009).

All control samples were submitted to the same conditions of other samples with $\mathrm{pH}$ and temperature variations, which may impact the AA, justifying the differences in the non-hydrolyzed samples. ALC presented the highest AA, followed by TRY, NPD and FLA. ALC achieved $46 \%$ after 300 min-reaction, while TRY and NPD presented similar profiles, ranging from $25 \%$ and $20 \%$ to $40 \%$ in both, respectively, as shown in Figure 3. FLA showed the lowest AA, with $22 \%$ after 300 min of reaction. Corroborating with the degree of hydrolysis and peptide profiles, samples presented a tendency to stabilize after 120 min-reaction.

Comparing hydrolysis processes with different enzymes, Dryáková et al. (2010) also found alcalase hydrolysates as the most effective in scavenging the ABTS+ radical, ranging from 19.8\% to $54.2 \%$, for non-hydrolyzed to $180 \mathrm{~min}$ hydrolyzed samples, respectively. Although the degree of hydrolysis impacts the antioxidant activity, there is also a structure-activity relationship between both, justifying the lower DH of ALC when compared to NPD, and the greater antioxidant activity of the further. (Dryáková et al., 2010; Madureira et al., 2010; Power et al., 2013). In this manner, according to the results presented, the hydrolysate obtained with alcalase may be considered as the most efficient when the aim is to produce a whey hydrolysate with high antioxidant capacity.

\subsection{Emulsifying capacity of whey hydrolysates}

The emulsifying capacity of proteins and peptides is related to their capacity to lower interfacial tension between hydrophobic and hydrophilic components into a food system (Bos \& van Vliet, 2001; Lam \& Nickerson, 2013).

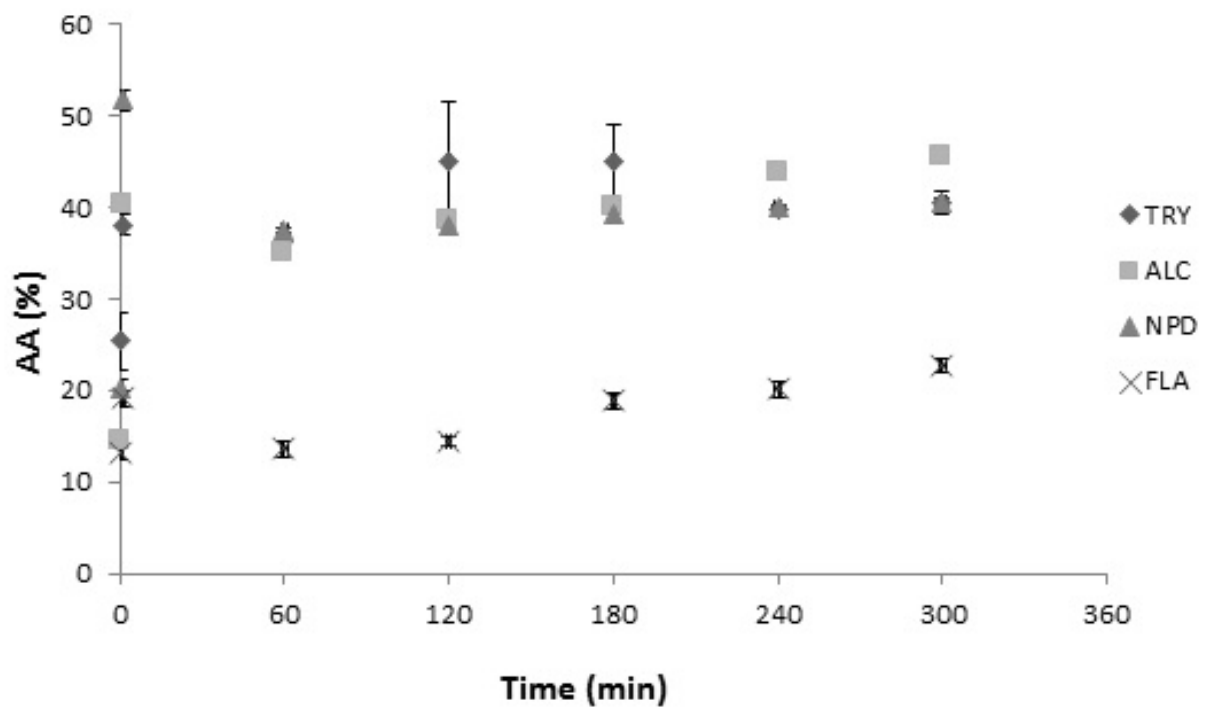

Figure 3. In vitro antioxidant activity of whey protein concentrate (WPC) hydrolysates. (ALC) alcalase, (NPD) novo pro D, (TRY) pancreas trypsin, and (FLA) flavourzyme. Measured by scavenge of the ABTS radical (ABTS•+). The antioxidant activity was calculated as AA\%. 


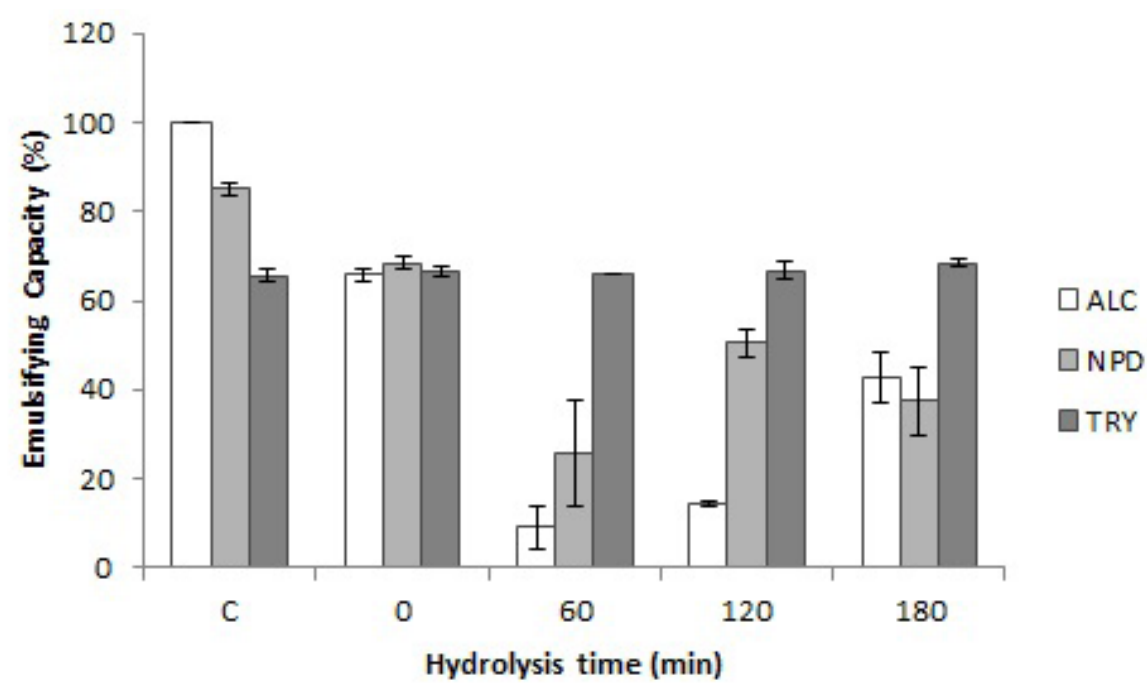

Figure 4. Emulsifying capacity of whey protein concentrate (WPC) hydrolysates. (ALC) alcalase, (NPD) novo pro D, (TRY) pancreas trypsin.

According to the results presented above, as FLA showed the lowest $\mathrm{DH}$ and $\mathrm{AA}$, this sample was not included into the EC activity. ALC, NPD and TRY had their EC\% assessed until 180 min-reaction (Figure 4), since after this time all the hydrolysates produced presented a tendency to stabilize their DH and AA, as shown in Figures 1 and 3. TRY hydrolysate showed a stable emulsifying capacity, which may be related with the low $\mathrm{DH}$ observed that promoted polypeptides generation. Larger size peptides are more likely to have both hydrophobic and hydrophilic residues on the same molecule, in which the hydrophobic residues interact with the oil droplets, while the hydrophilic ones will favor the aqueous phase and stabilize the droplets through steric effects. Adjonu et al. (2014) also related trypsin hydrolysates with high interfacial adsorption, emulsifying capacity and good storage stability. NPD presented an intense decrease on EC after $60 \mathrm{~min}$, going from 85 to $26 \%$, and after 120 - 180 min-hydrolysis the EC increased, and reached 50\% within 120 minutes. ALC emulsifying capacity assays also presented certain instability, with a high decrease in 60-min hydrolysis, reaching $9 \%$, followed by a significant increase at $180 \mathrm{~min}$, rising from $9 \%$ to $42 \% \mathrm{EC}$.

Different protein characteristics may affect its emulsifying activity, including $\mathrm{pH}$, temperature and protein hydrolysis. In general, low $\mathrm{DH}$ retain or increases this functionality, whereas intense hydrolysis diminishes it since peptides are too short to act as effective emulsifiers, saturating the continuous phase rather than adhering to the water-oil interface (Lam \& Nickerson, 2013; Wani et al., 2015). Dual-functional peptides are of great interest for food industries, since it aggregates both technological and biological functions, increasing the added value of a product. Among the hydrolysates obtained, the fraction hydrolyzed with trypsin presented a stable emulsifying capacity along the experiment and a tendency to stabilize its antioxidant activity after $2 \mathrm{~h}$-reaction. In this sense, the $120 \mathrm{~min}$ tryptic hydrolysate may be considered the best condition for obtaining peptides with both antioxidant and emulsifying capacities.

\section{Conclusion}

This study dealt with a comparison of WPC hydrolysates by the use of commercial proteases. Alcalase and Novo pro-D presented the highest hydrolysis degrees, corroborating with their peptide profiles, which showed some similarities. According the RP-HPLC chromatograms, all enzyme treatments presented a tendency to stabilize after 120 min-reaction. The same tendency was observed for the antioxidant activity analyses, which revealed ALC hydrolysate as the most capable of scavenging the radical ABTS+, followed by TRY, NPD and FLA hydrolysates. Pancreas Trypsin showed an average emulsifying activity, while Novo Pro-D and Alcalase showed satisfactory results towards this property. In this sense, among tested enzyme, ALC, TRY and NPD could be used for producing dual-functional hydrolysates, especially the 120 min fraction of TRY hydrolysate, which presented high antioxidant activity and emulsifying capacity.

\section{Acknowledgements}

The authors would like to thank the Brazilian agencies Fundação Carlos Chaga Filho de Amparo à Pesquisa do Estado do Rio de Janeiro (FAPERJ), Conselho Nacional de Desenvolvimento Científico e Tecnológico (CNPq) and Empresa Brasileira de Pesquisa Agropecuária (EMBRAPA) for their financial support. The authors also thank Alibra Ingredientes Ltda and Novozymes Latin America for supplying WPC and enzymes, respectively.

\section{References}

Adjonu, R., Doran, G., Torley, P., \& Agboola, S. (2014). Whey protein peptides as components of nanoemulsions: A review of emulsifying and biological functionalities. Journal of Food Engineering, 122, 15 27. http://dx.doi.org/10.1016/j.jfoodeng.2013.08.034.

Adler-Nissen, J. (1986). Enzymatic hydrolysis of food proteins. New York: Elsevier Applied Science Publishers. 
Bos, M. A., \& van Vliet, T. (2001). Interfacial rheological properties of adsorbed protein layers and surfactants: A review. Advances in Colloid and Interface Science, 91(3), 37-471.

Cánovas, G. V. B., Pastore, M. G., Candoğan, K., Meza, I. G. M., Lannes, S. C. S., Buckle, K., Yada, R. Y., \& Rosenthal, A. (2017). Global Food Security and Wellness. New York: Springer. http://dx.doi. org/10.1007/978-1-4939-6496-3.

Cheison, S. C., Schmitt, M., Leeb, E., Letzel, T., \& Kulozik, U. (2010). Influence of temperature and degree of hydrolysis on the peptide composition of trypsin hydrolysates of b lactoglobulin: Analysis by LC- ESI-TOF/MS. Food Chemistry, 121(2), 457-467. http://dx.doi. org/10.1016/j.foodchem.2009.12.065.

Dryáková, A., Pihlanto, A., Marnila, P., Čurda, L., \& Korhonen, H. J. T. (2010). Antioxidant properties of whey protein hydrolysates as measured by three methods. European Food Research and Technology, 230(6), 865-874. http://dx.doi.org/10.1007/s00217-010-1231-9.

Hernández-Ledesma, B., Recio, I., \& Amigo, L. (2008). $\beta$-Lactoglobulin as source of bioactive peptides. Amino Acids, 35(2), 257-265. http:// dx.doi.org/10.1007/s00726-007-0585-1. PMid:17726638.

Lam, R. S. H., \& Nickerson, M. T. (2013). Food proteins: A review on their emulsifying properties using a structure-function approach. Food Chemistry, 141(2), 975-984. http://dx.doi.org/10.1016/j. foodchem.2013.04.038. PMid:23790876.

Le Maux, S., Nongonierma, A. B., Barre, C., \& FitzGerald, R. J. (2016). Enzymatic generation of whey protein hydrolysates under $\mathrm{pH}$-controlled and non $\mathrm{pH}$-controlled conditions: Impact on physicochemical and bioactive properties. Food Chemistry, 199, 246-251. http://dx.doi. org/10.1016/j.foodchem.2015.12.021. PMid:26775967.

Madadlou, A., \& Abbaspourrad, A. (2017). Bioactive whey peptide particles: An emerging class of nutraceutical carriers. Critical Reviews in Food Science and Nutrition, 58(9), 1-10. PMid:28001086.

Madureira, A. R., Tavares, T., Gomes, A. M., Pintado, M. E., \& Malcata, F. X. (2010). Invited review: physiological properties of bioactive peptides obtained from whey proteins. Journal of Dairy Science, 93(2), 437-455. http://dx.doi.org/10.3168/jds.2009-2566. PMid:20105516.

Mellinger-Silva, C., Rosa, L. O. L., Stephan, M. P., Brígida, A. I. S., Cabral, L. M. C., Silva, G. O., Guarido, K. L., Gomes, D. M., \& Silva-Santos, J. E. (2015). Dual function peptides from pepsin hydrolysates of whey protein isolate. International Dairy Journal, 48, 73-79. http:// dx.doi.org/10.1016/j.idairyj.2015.01.016.
Mordor Intelligence (2017). Whey Protein Market | Growth | Trends | Size | Analysis (2017-2022). Hyderabad: Mordor Intelligence. Retrieved from https://www.mordorintelligence.com/industry-reports/globalwhey-protein-market-industry\#tab-1.

Ojha, K. S., Alvarez, C., Kumar, P., O’Donnell, C. P., \& Tiwari, B. K. (2016). Effect of enzymatic hydrolysis on the production of free amino acids from boarfish (Capros aper) using second order polynomial regression models. Lebensmittel-Wissenschaft + Technologie, 68, 470-476. http://dx.doi.org/10.1016/j.lwt.2015.11.040.

Power, O., Jakeman, P., \& FitzGerald, R. J. (2013). Antioxidative peptides: enzymatic production, in vitro and in vivo antioxidant activity and potential applications of milk-derived antioxidative peptides. Amino Acids, 44(3), 797-820. http://dx.doi.org/10.1007/ s00726-012-1393-9. PMid:22968663.

Re, R., Pellegrini, N., Proteggente, A., Pannala, A., Yang, M., \& RiceEvans, C. (1999). Antioxidant activity applying an improved ABTS radical cation decolorization assay. Free Radical Biology \& Medicine, 26(9-10), 1231-1237. http://dx.doi.org/10.1016/S0891-5849(98)003153. PMid:10381194.

Sultana, M. Y., Mourti, C., Tatoulis, T., Akratos, C. S., Tekerlekopoulou, A. G., \& Vayenas, D. (2016). Effect of hydraulic retention time, temperature, and organic load on a horizontal subsurface flow constructed wetland treating cheese whey wastewater. Journal of Chemical Technology and Biotechnology (Oxford, Oxfordshire), 91(3), 726-732. http://dx.doi.org/10.1002/jctb.4637.

Wani, I. A., Sogi, D., Shivhare, U. S., \& Gill, B. S. (2015). Physico-chemical and functional properties of native and hydrolyzed kidney bean (Phaseolus vulgaris L.) protein isolates. Food Research International, 72, 11-18. http://dx.doi.org/10.1016/j.foodres.2014.08.027.

West, D. W. D., Abou Sawan, S., Mazzulla, M., Williamson, E., \& Moore, D. R. (2017). Whey protein supplementation enhances whole body protein metabolism and performance recovery after resistance exercise: A double-blind crossover study. Nutrients, 9(7), 735. http:// dx.doi.org/10.3390/nu9070735. PMid:28696380.

Whipple, T. J., \& Eckhardt, R. B. (2016). The Endurance Paradox: Bone Health for the Endurance Athlete. New York: Routledge. http://dx.doi. org/10.4324/9781315418650.

Zulueta, A., Esteve, M. J., \& Frígola, A. (2009). ORAC and TEAC assays comparison to measure the antioxidant capacity of food products. Food Chemistry, 114(1), 310-316. http://dx.doi.org/10.1016/j. foodchem.2008.09.033. 